\title{
It's About Time: Re-Imagining Present and Future Times in Art, Education and Sustainable Development
}

\author{
Raphael Vella, Censu Caruana, and Charmaine Zammit
}

\begin{abstract}
This chapter argues for a model of art education informed by the sustainable development goals and education for sustainable development. It explores connections between the discourses of contemporary art, particularly socially engaged forms of art, and sustainable development through the temporal lens of present and future, arguing that any transformative outlook on our understanding of development, education and art must first engage with the social and political realities of present times, as demonstrated in the work of many artists. Transformative and reconstructionist conceptions of teaching and learning are considered, while the fourth pillar of sustainability, culture, is seen as a bridge that could reposition and broaden debates on art education within the political goals of education for sustainable development and its competencies. In particular, the activist and collaborative dimensions of contemporary art, its sense of wonder and uncertainties are seen as overlapping concerns in art education and education for sustainable development. This leads towards inquiry-based pedagogies that open the door to a sense of agency that is relevant both to art and to all those who believe in the possibility of change.
\end{abstract}

\section{A Matter of Time: The Eyes of All Future Generations}

A connection between the concept of sustainable development (SD) and contemporary art revolves around our relationship with the future. Discourse on SD is replete with references to time, especially future time. In 1987, the Brundtland report famously characterised SD as a "development that meets the needs of the

\author{
R. Vella $(\bowtie) \cdot$ C. Caruana $\cdot$ C. Zammit \\ University of Malta, Msida, Malta \\ e-mail: raphael.vella@um.edu.mt \\ C. Caruana \\ e-mail: censu.caruana@um.edu.mt \\ C. Zammit \\ e-mail: charmaine.zammit.00@um.edu.mt
}


present without compromising the ability of future generations to meet their own needs" (IISD n.d.). A few years later, the 1992 Rio Summit reiterated this goal in Principle 3, which affirmed the importance of meeting "developmental and environmental needs of present and future generations" by establishing a global partnership (United Nations, 1993, p. 3).

Boycotted by the United States' President G. W. Bush, yet attended by children who gave an introductory speech, the Johannesburg World Summit in 2002 was also unequivocal about its commitment to a future time that belonged to the world's children, who would supposedly "inherit a world free of the indignity and indecency occasioned by poverty, environmental degradation and patterns of unsustainable development" (United Nations, 2002, 1). In 2019, however, it was palpably obvious that children had not yet inherited that future world when a 16-year-old Greta Thunberg denounced the failings of world leaders at the U.N.'s Climate Action Summit in New York City, reminding them that the "eyes of all future generations are upon you" (UN News, 2019, para. 1).

The discourse of modern and contemporary art has also focused, periodically, on articulations of the present, past and future. During the twentieth century, dreams of human progress, radical departures in history and political utopias accompanied modern artistic and cultural movements, manifestoes and exhibitions, especially in the West. More recently, the Arab Spring led many to wonder whether a radically different future could also be imagined in the Arab world. However, the troubles in that region, as well as the uncertainties of a European continent shaken by right-wing appropriations of democracy, are making many people involved in the arts ask today whether it is even plausible to imagine the world through Thunberg's "eyes of all future generations":

To imagine the future of freedom necessarily requires looking at the present situation. What place does the concept of freedom have in our contemporary world? Is freedom and its supposed counterpart - democracy - possible for everyone or achievable by only a select few? Or does the power of democracy or democratic power stand in the way of freedom? And what does this mean for the free or liberal arts, which are under such enormous pressure in the current political climate? (Folkerts, 2015, 13)

Only by engaging with misgivings about present cultural phenomena can people imagine future democratic reform and develop a sense of agency. This is not a reversal of the central message of the Brundtland report, which urges present generations not to be blinded by "progress" to the extent of ignoring the needs of future generations. Rather, this construction of a possible horizon on the anxieties of the present has been the strategy of many climate activists, including Thunberg, as well as artist-activists involved in political affairs in other historical periods (Fig. 1).

For example, the revolutionary nineteenth-century Realist painter Gustave Courbet, well-known for his involvement in the Paris Commune and his association with Pierre-Joseph Proudhon's anarchism, painted the materiality of contemporary, lived experience so directly that his critics responded with hostility: "Ugliness, ugliness forever! And ugliness with no great character, ugliness without the beauty of 


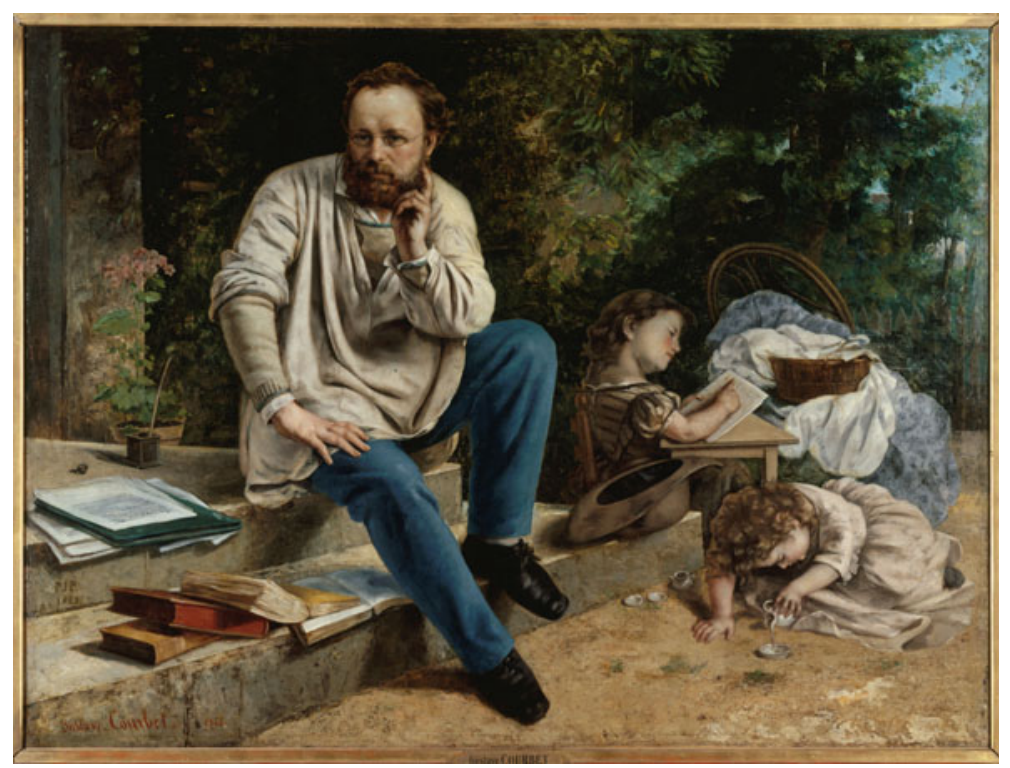

Fig. 1 Gustave Courbet, Pierre-Joseph Proudhon and his children in 1853 (painted in 1865), oils on canvas, CC0 Paris Musées / Musée des Beaux-Arts de la Ville de Paris, Petit Palais

ugliness!" (Tinterow \& Loyrette, 1994, 362). By discarding idealism and mythological narratives, Courbet paved the way for modern art and its depiction of cities, current ways of life and popular culture.

Art theorist Boris Groys has located the idea of the new or the avant-garde in art in the intersection between what already exists around us (the present) and what has been archived (the past). For Groys, art's claim to political relevance lies precisely in the way it helps to give value to existing things by placing them in the realm of the valorised or protected (places like museums), which works to "sustain" these things and pushes artists to revalorise "new" values and things (Groys, 2014a, b). This is how the present finds a place in and simultaneously shakes the archives of the past, pointing towards future revaluations of cultural hierarchies.

A similar idea is expressed in Nicolas Bourriaud's The Exform (2016), in which he draws parallels between Courbet's realistic principles and a contemporary fascination with waste, which brings "those expelled by ideology, deported from symbolic power, back to the centre of life and culture" (97). This is also why the agenda in debates on SD_previously centred almost exclusively around environmental, "green" issueshas been supplemented with principles of social justice in recent decades: the future of the neglected (those who are fleeing from war and discrimination, exploited workers and women, ecosystems that are threatened by unsustainable expansion, and so on) can only be transformed if we can afford to revaluate social hierarchies in the present.

For many, such a transformation will not be viable if it is not supported by a more critical approach to the field of education. The idea of a "transformative" 
potential for teaching and learning has roots in the work of various educational theorists, such as Freire (1970), Mezirow (1991) and others, who have stressed the centrality of autonomous thinking, self-direction and ongoing revisions of internalised misconceptions and beliefs in learning environments. While different conceptions of transformative learning, particularly in the field of adult education, place varying emphases on individual transformation and social change, some theorists have pushed for more holistic understandings of transformative learning that incorporate affective modes and a planetary perspective which "recognizes the interconnectedness among universe, planet, natural environment, human community, and personal world" (Taylor, 2008, 9). An awareness of this interconnectedness shows that global partnerships are necessary in present times to ensure that the value of economic growth does not eclipse the possibility of real SD in the future.

In art education, the last few decades have seen the growth of reconstructivist approaches to the field, pushing for the use of art as a "tool for the analysis of social conditions and values" (Siegesmund, 1998, 203). A reconstructivist art education contextualises art and education in current societal needs and aspirations, contrary to expressionist approaches that focus on individual creative expression and the development of the imagination (Hickman, 2010, 41-42). This approach can also acquire a direct, political goal, as evidenced in the sociology of aesthetic education espoused by Lena Aulin-Gråhamn and Jan Thavenius and others in Nordic countries: such scholars "advocate a radical aesthetics, inspired by the art world, as an alternative to the modest aesthetics, prevailing in schools, and the market aesthetics, which dominate the aesthetic field" (Lindström, 2009, 72). On par with current literature about education for sustainable development (ESD), recent debates about mainstream art education and art beyond institutional frameworks, such as community-based art education and co-design practices, have recognised the role of the arts in engaging with cultural challenges, economic development and issues of social justice (Quinn et al., 2012; Bell \& Desai, 2014; Harris Lawton et al., 2019). This emphasis on the situated nature of learning, ethical responsibilities, participatory design processes and a multidisciplinary expansion of the field of art education challenges established hierarchical boundaries and canons and also links up well with the collaborative goals and four pillars (social, environmental, economic and cultural) of ESD.

The real challenge for art education now is to ensure that this broadening of the field is reflected in actual classroom practices, which are still often characterised by expressionistic and individualistic methodologies. A radical approach to ESDinfused art education requires participatory teaching and learning strategies that motivate and empower students to transform their attitudes and behaviour in order to take action in the world. When learners take control of their learning and become participants in the act of teaching, education becomes more interactive and contributes to a stronger sense of responsibility.

Further connections between art education and ESD can also be studied in the work of many contemporary artists who address both a "green" agenda (related to natural ecosystems, for instance) and a "brown" agenda for sustainability (exploring hazardous waste, energy consumption, water, and so on) and other goals of SD listed by UNESCO. These connections are not stable; they exist in a state of flux, 
given that current social and economic conditions are fragile and changing, while teleological aims for art remain unrealistic. Artists and collectives today register singular contact points, exchanges and tensions, reflecting the rawness of the here and now by using any material at hand. A few examples below can serve to demonstrate the vast potential of this field of study.

Engagements with ecological issues and associated effects, such as the impact of unmitigated economic growth and pollution on indigenous lives, have been addressed by many contemporary artists, and are sometimes summed up as various forms of ecoart. The materials used by artists sometimes amplify sustainability issues. Ghanaian artist El Anatsui recycles African materials like bottle caps to stitch vast tapestries that combine an undeniable beauty with tales of consumption and poverty. American artist Michael Rakowitz has constructed shelters for homeless people with materials like polyethylene and tape in his paraSITE series, using the warm air emitted from buildings' heating, ventilation and air conditioning systems to inflate and heat these temporary homes. In 2008, Brazilian-American artist Vik Muniz worked with "catadores" (garbage pickers) in Jardim Gramacho near Rio to make monumental portraits out of trash, a lengthy process that led to the moving documentary Waste Land in 2010.

Weintraub (2012) has usefully indexed many specific examples and approaches to eco-art, listing artists and collectives who have worked in fields like conservation, preservation, urban ecology, industrial ecology and SD. According to Weintraub, ecoart is innovative when it reflects changes taking place in society, when it addresses the global and ecological uncertainties of contemporary life and when it includes "utilitarian strategies" (6). Its relationship with time is often dynamic, sometimes making use of ephemeral materials that respond to their environment by melting or even dying (Fig. 2).

In 2018, the Danish-Icelandic artist Olafur Eliasson, together with geologist Minik Rosing, fished several large blocks of ice from a fjord in Greenland and shipped them in refrigerated containers to London, where they were installed in public spaces and left to melt. The installation, Ice Watch, had first been set up in Copenhagen in 2014, and the second installation had taken place in Paris in 2015. For the third time, the installation in London exposed members of the public to the fact that billions of tonnes of glacial ice are lost in Greenland every year as a result of a massive increase in carbon dioxide emissions. This is how contemporary art quotes directly from the past by revalorising and relocating ancient blocks of compressed ice to contemporary London, in an effort to raise awareness about rising global sea levels and global warming.

An installation like Ice Watch also points towards another feature of contemporary art-its fusion of art and life. Artistic forms mirror forms of life in order to echo and simultaneously resist them; for instance, by bridging the gap between work and audience in participatory artistic practices, reflecting civic participation in the process. Artists who work in the field of social practice do not ask whether their work can still be called art but whether it translates well into the contexts of lived experience. 


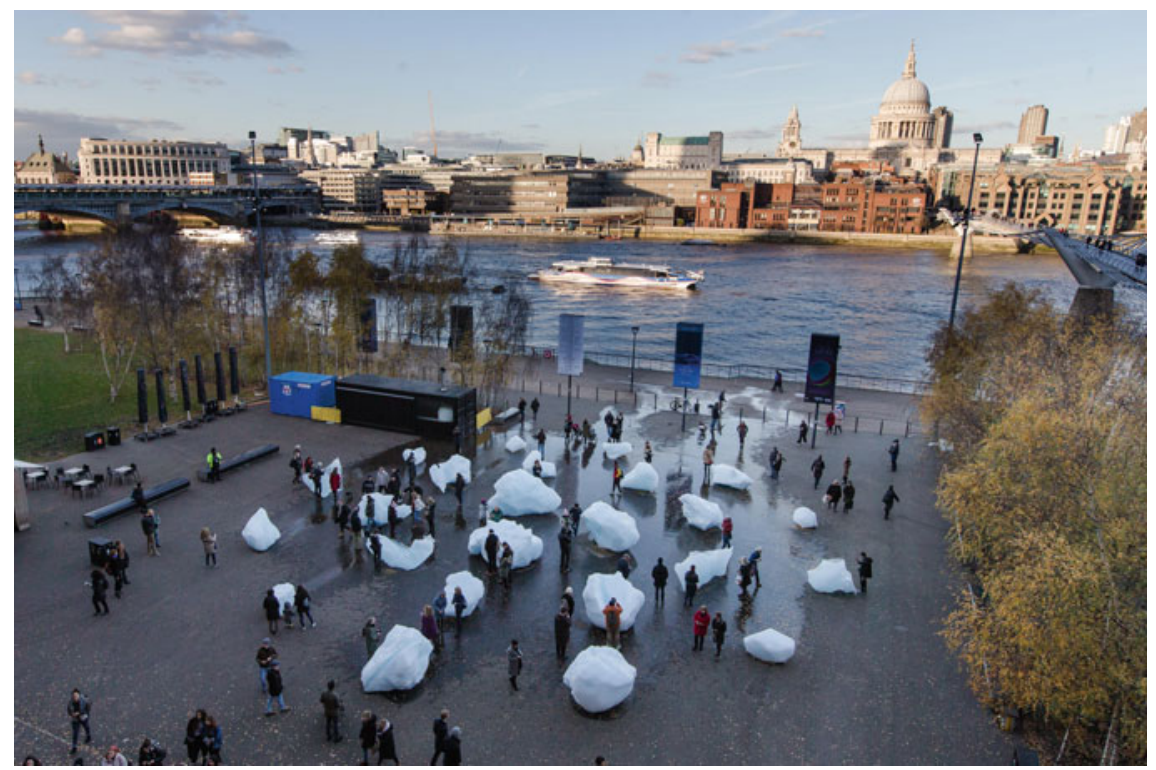

Fig. 2 Ice Watch by Olafur Eliasson and Minik Rosing, Supported by Bloomberg, Installation: Bankside, outside Tate Modern, 2018, Photo: Charlie Forgham-Bailey. (C) 2018 Olafur Eliasson

Considering the relationship between art and life in social practice, curator Nato Thompson suggests that we stop trying to establish whether this new type of work is art. Instead, he recommends that we ask this question: "If this work is not art, then what are the methods we can use to understand its effects, affects, and impact?" (Thompson, 2012, 26). It is a question that would be pertinent to ask when faced with the work of many socially engaged artists today. American artist Suzanne Lacy has combined artistic media like film and performance with non-conventional "media" like dialogue and civic action to explore stories of female victims of abuse and legal and institutional lacunae that work against women. Cuban artist Tania Bruguera has used pedagogical and activist methods to empower migrants and examine the abuses of power in different contexts.

The integration of art and life does not merely replicate current models of life but offers "utilitarian" counter-models that highlight the political impact that Thompson refers to as well as the urgency for action. This political dimension is also evident in the development of ESD. The following section starts with a cursory historic overview of recent global processes in the advancement of ESD. It then positions the arts and arts education in such processes and considers what can be the specificities and comparative advantage of the arts in the advancement of ESD. 


\section{Sustainable Development and Education for Sustainable Development}

Definitions of SD abound, yet the one that is most quoted is that popularised through the Brundtland Report, cited earlier in this chapter. The foundation of SD is the inherent interdependence between the environment and the economy and the search for win-win solutions where a trade-off between the two is not necessary (Emas, 2015). The acknowledgement that the long-term stability of the environment and the economy is "only achievable through the integration and acknowledgement of economic, environmental, and social concerns" (Emas, 2015, 2) led to the popularisation of the three-pillars concept of SD, arguing that SD takes place where such concerns intersect. This model, however, led to a growing unease that something fundamental was missing, with various attempts to describe the "fourth pillar" as lying within the realms of the cultural/aesthetic (Burford et al., 2013).

Hawkes (2001) specifically argued for culture to be recognised as the fourth pillar of sustainability, arguing that cultural vitality is an essential component of a healthy society. In 2010, the Executive Bureau of United Cities and Local Governments agreed on a Policy Statement acknowledging culture as the fourth pillar of sustainable development, on the realisation that the three pillars " ... alone cannot possibly reflect the complexity of current society ... culture ultimately shapes what we mean by development and determines how people act in the world" (UCLG, 2010, 4).

When the United Nations declared the decade between 2005 and 2014 as the Decade of Education for Sustainable Development (DESD), it sought to reorient all education towards sustainability (UNESCO n.d.-a). While acknowledging that education is not the panacea to the sustainable development challenges the world is facing, it did consider that without education, a sustainable future will not be possible. Subsequently, the DESD was followed up by the Global Action Programme (GAP), which ran till 2019, and sought to "generate and scale up action in all levels and areas of education and learning to accelerate progress towards sustainable development".

GAP took a two-pronged approach, namely that of both integrating sustainable development into education and vice versa (UNESCO n.d.-b). However, in spite of the efforts and progress that took place over the 15 years of DESD and GAP, UNESCO observed that: "With accelerated climate change the fragility of our planet is becoming more and more apparent. Persistent inequalities, social fragmentation, and political extremism are bringing many societies to a point of crisis" (UNESCO n.d.-c). The education imperative became even more urgent. Within this context, UNESCO initiated the Futures of Education: Learning to Become initiative, aiming to "catalyse a global debate on how knowledge and learning can shape the future of humanity and the planet" (UNESCO n.d.-c). The vision of this process is for education to go beyond that of responding to the changing world, but rather to claim its transformative role and to act together to create the futures that we want. This process is running in parallel to the sustainable development goals (SDGs), a series of 17 interdependent goals adopted in 2015 that aim to "address the global challenges 
we face, including those related to poverty, inequality, climate change, environmental degradation, peace and justice" (UN, n.d.). Of particular note is SDG 4.7:

"By 2030 ensure all learners acquire knowledge and skills needed to promote sustainable development, including among others through education for sustainable development and sustainable lifestyles, human rights, gender equality, promotion of a culture of peace and non-violence, global citizenship, and appreciation of cultural diversity and of culture's contribution to sustainable development."

Here we can also appreciate the significance of the fourth pillar of sustainability within ESD, with a "strong focus on acknowledging and respecting diverse worldviews, identities and local languages and promoting open dialogue and debate" (Burford et al., 2013, 3036).

It is beyond the scope of this chapter to discuss the various models of how ESD can be integrated across different curricula at various levels. However, one approach that has taken steam since the early debates on ESD is not to claim a "slice of the pie" among competing curricular subjects, but rather to ensure sustainability as a strong foundational structure for all subjects. This model also seeks to go beyond the "privileged" subjects in the infusion of sustainability, such as science or geography, but rather acknowledge all subjects equally as potential vehicles for the infusion of sustainability across the curriculum. Furthermore, within such understanding, the learner's environment, both within and outside the school, becomes a fundamental teaching resource that is locally relevant and culturally sensitive. In a "whole school approach" to infusing ESD across the curriculum, the school becomes a microcosm of the world we want to create or the future we envision. This is described by the Global Education Monitoring Report (2016) as incorporating "all aspects of a school: curriculum, extracurricular activities, teacher training, human resources, infrastructure, operations and processes".

\section{Repositioning Art Within the ESD Debate}

Two questions that follow logically from such a model of integrating ESD across the curriculum in a whole school approach are: (a) "How can art education position itself as a significant contributor in this urgent task of reorienting education towards sustainability?" and (b) What is specific to art education in reorienting education towards sustainability? Such questions come with their own dilemmas, in that already art education is often a subject of lesser status within various educational contexts. To answer these questions, we need to consider four points:

1. Competencies pertaining to ESD and art education

2. Art education as a vehicle to strengthen the fourth pillar of SD

3. Art education and the future of humanity

4. Art as a channel of hope. 


\section{Competencies Pertaining to ESD and Art Education}

The Arizona State University in 2011 identified the following five competencies as a reference framework for academic programme development in ESD: systems thinking competency; futures thinking (anticipatory) competence; values thinking (normative) competence; strategic competence; and interpersonal (collaboration) competence. Competencies with respect to art education are more controversialin that some would argue that a subject that revolves around creativity cannot be prescribed by strict competencies. This has been summarised brilliantly by Atkinson (2010) who asked the question: "Do such redistributions return us to a pedagogical consideration of the importance of 'not knowing' and the passion of 'wonder' in learning? (1)". Here, however, there is no necessary dissonance with ESD competencies, in that there are arguments that "we will not solve the environmental crisis (and reach a sustainable future) without a change in worldview to ecocentrism and a rejuvenation of humanity's sense of wonder toward nature" (Washington, 2018, 14).

Furthermore, there have also been various attempts to enlist competencies and goals of art education. Eisner's (2002) ten goals of art education, which are often applied in the art curricula of schools worldwide, run parallel to the ESD competencies promoted by UNESCO (2019), such as "critical thinking", "imagining future scenarios" and "making decisions". Some of the goals that Eisner outlines for art education are the ability to make moral judgements, rather than seeking correct answers, the embracing of multiple viewpoints, the acceptance of unforeseen possibilities in the creation of artworks, the making of small differences which eventually create large impacts and the communication of feelings and ideas that students usually find hard to express. On the other hand, the Royal Academy of Art, The Hague (2020) suggests the following competencies: creative ability; capacity for critical reflection; capacity for growth and innovation; organisational ability; communicative ability; external awareness and capacity for collaboration. Here one can notice various explicit and implicit synergies between the ESD and art education competencies, such as collaboration competencies, external awareness and critical thinking. When one then considers that domain of art as activism with its focus on social change and on the "ability of art to function as an arena and medium for political protest and social activism" (Groys, 2014a, b para. 1), then there is a very clear explicit match with ESD competencies such as systems thinking, anticipatory and strategic competencies.

\section{Art Education as a Vehicle to Strengthen the Fourth Pillar of SD}

As outlined earlier, SD has adopted a four-pillar framework that encompasses the economic, social, environmental and cultural pillars. In practice, on a global and national level, the economic pillar often takes precedence. However, within an SD 
understanding, the "privileged" economic pillar needs to shrink and allow more space for the environmental and social pillars to find their place, within a context that is sensitive to intangible aspects such as values, customs, rituals and life patterns. Here the arts are a fundamental part of the cultural pillar, which when reflected in education offers all students the opportunity to actively participate in arts practices. According to Hawkes $(2001,24)$, "creativity, engagement, cohesiveness, wellbeing and respect for difference will be inevitable outcomes".

Given that an artistic approach in education could create a space for students to reflect critically on their everyday life actions, art education plays an important role in global issues concerning sustainability (Macdonald \& Jónsdóttir, 2014), hence strengthening the fourth pillar of SD. The multidirectional content of art and culture promotes aesthetic sensitivity and critical thinking skills while the cultivation of values of sensitivity and empathy empowers students to protect the environment and develop respect for society (Özsoy, 2016). By developing thematic projects that embrace the cultivation of personal and social responsibilities, students become aware of national and global issues such as disaster risk reduction, biodiversity, poverty reduction and sustainable consumption. In turn, students' actions, especially if displayed in physical exhibitions or virtually, help to raise awareness about the importance of working collaboratively to address global issues. The cultural pillar of SD underlines the importance of different forms of collaboration; without exchanges and disagreements, culture wouldn't exist. Participatory practices can redefine pedagogies, understandings of subjectivity and the meanings of being together in the world, leading towards an Art Education for Sustainable Development, or AESD (Illeris, 2017).

\section{Art Education and the Future of Humanity}

The multifaceted nature of collaboration leads us to another parallel between ESD and art education. It is acknowledged that ESD deals with complex issues that threaten sustainability. Here art education can be an important tool in dealing with complexity, as well as expressing the contradictions of the current dominant paradigm with its skewed focus on technological fixes. Visual art in particular has the power to transmit and express such complexity and contradictions in a way that arrives at the heart, that liberates the voice, expression and creativity of students, inviting them to reflect critically and act accordingly. This is very much in line with UNESCO's Futures of Education and its invitation to open up new spaces for debate on how education needs to be "reimagined in a world of increasing complexity, uncertainty, and precarity" (UNESCO n.d.-c., para.1). 


\section{Art as a Channel of Hope}

One characteristic of ESD (and related educations such as Global Citizenship Education and Environmental Education) is the invitation to move beyond knowledge and awareness into action. Such actions are understood both at an individual level and at an organisational level, which can be the school or the educational institution. Within such an understanding, teachers and educators are invited to structure learning experiences around the identification and resolution of sustainable development issues that equip and empower learners with problem-solving and decision-making skills. The focus is never the problem but an understanding of the problem to move towards inspired action and solutions. Here art education can play an important role.

Kumar (2010) argues that from the Renaissance onwards art was often confined to those with special talent and artists tended to work as individuals in their studio, producing mainly items of luxury and status, but this is being challenged by people with ecological and social sensibility. He contends that when "artists let go of their egos and their wish for celebrity status and personal glory, then art becomes truly boundless" (Kumar, 2010, 166). A rather bold statement, yet his argument is that art is both a force for transformation and self-realisation.

When art education embraces a sustainability-based pedagogy, standardised curriculum models get disturbed because such approaches re-envision the purpose of education. We need to consider a model of art education that works to reinforce the fourth cultural pillar of ESD by promoting students' active participation through a process of social, environmental, economic and cultural transformation, which is currently required to safeguard a sustainable present and future for all. Such a model would not simply offer a recipe curriculum with a fixed body of content knowledge, activities and themes. Instead, recognising the relations between ESD and art education described earlier, it would revolve around questions that demand students' creative approaches to unsustainable development and the application of critical and creative thinking for individual and collaborative problem-solving.

When one considers the compatibility and synergies between the competencies pertaining to ESD and those of art education and the potential of art education to reinforce the four-pillar model of ESD, art education and its transformative potential need to be better acknowledged as a crucial vehicle in the global project of reorienting education towards sustainability. As challenged by SDG 4.7 and Futures of Education, we require new conversations around art education to ensure critical thinking and corresponding actions to co-create the world we want and, in the words of Kumar (2010), "unlock the doors of optimism and hope" (p. 166).

In spite of this sense of optimism, though, education can become complicit in the erosion of ecology and community (Graham, 2007). Although educators can include sustainability issues by referring to contemporary artists like those referenced earlier in this chapter, in practice they often avoid referring to contemporary art and visual culture (Wilson, 2003). The problematic relationship between traditional approaches to art pedagogy and issues of gender, power, privilege, political and social change have been analysed in the field of visual culture art education (for instance, Freedman, 
2003). Consequently, the exclusion of sustainability issues neglects the potential of art to educate and eventually to encourage activism that brings about ecological, social and cultural transformations (Graham, 2007). As the strategy for ESD developed by the United Nations Economic Commission for Europe (UNECE) steering committee has stated on Learning for the Future (UNECE, 2012), a transformative pedagogy also requires a transformation of what it means to be an educator, leading to situations in which educators "present themselves as fallible human beings rather than people with all the answers" (17). Rather, such a pedagogy would necessitate an inquirybased approach, making use of questions that may offer students a starting point to a journey of discovery using art as a visual means to engage with reflections concerning unsustainable personal, social, cultural and other settings. Below are two examples.

\section{Where Are You from?}

A common question, "Where are you from?", can be approached through the use of map-making, a procreative learning activity that develops visual thinking and ecological literacy (Sobel, 1998). An inquiry-based approach that raises conversations ranging from physical geography to cultural boundaries and personal experiences can stimulate students' interdisciplinary art-making. Beyond the topographic features of maps and neighbourhoods, students may investigate physical and mental borders that affect sustainable development goals related to infrastructure, industry, sanitation, communities, access to open spaces and inequalities. This focus on the social and changing aspects of art and places helps both learners and educators to conceive of curriculum as an organic, imaginative process that reflects realities in our present times as well as possible meanings of active citizenship in the "Not Yet" times often addressed by artist Jeanne van Heeswijk:

How do we train ourselves to work within a collective body towards a shared desire of how to live when we cannot identify the collective body yet? How do we preenact our learning into the future? (van Heeswijk and Rendón, 2018, 246)

\section{What Do I See?}

Traditionally, art connected drawing to the exploration of the natural world, as can be indicated by the numerous nature studies in sketchbooks of artists like Leonardo da Vinci and Albrecht Dürer. The history of landscape painting and biological illustrations are both practices of this tradition. Keeping in mind the question "what do I see?" may stimulate the students' drawing from observation of the natural world which involves both a research and discovery practice. It connects students' drawing processes to scientific investigation, leading them to understand and appreciate the world (Marshall, 2004) while getting familiar with local ecology (Erzen, 2005). Moreover, this question can be a starting point to cultivate students' awareness of 
different ways of seeing and link art to natural history, scientific observation and a concern with the natural environment. A keen sense of observation helps us to develop an awareness of current challenges faced by both terrestrial and aquatic forms of life.

\section{Conclusion}

Despite its often marginalised position in an educational system that emphasises curricular standardisation and high stakes testing (Eisner, 2005), art can make its unique contribution to a more humane, sustainable society. When arts pedagogies are framed by vital questions concerning personal, environmental, community and cultural issues, they create opportunities for both teachers and students to engage in an investigation of SD issues through a socially responsive process of reflective and transformative learning. An art education that is informed by ESD explores the spaces, social and cultural hierarchies and social processes that surround us in present times in order to interpret future possibilities. This is not a simple dichotomy that separates the known from everything that is not yet known. Current realities present a measure of ambiguity that allows for multiple interpretations too. Perhaps, the quality that brings art and ESD closest to each other is agency: the ability to assess consequences or results and act in a given situation, social environment and/or space. Agency is the capacity to take action now and navigate possible futures. This "anticipatory competence" engages with change and the malleability of the future, forming new worldviews in the process.

\section{References}

Atkinson, D. (2010). Looking awry at the notion of core competences in visual art education. Retrieved May 26, 2020, from http://www.unesco.org/new/fileadmin/MULTIMEDIA/HQ/CLT/ CLT/pdf/fpdennisatkinson106.pdf

Bell, L. A., \& Desai, D. (Eds.). (2014). Social Justice and the Arts. New York and London: Routledge.

Burford, G., et al. (2013). Bringing the "missing pillar" into sustainable development goals: Towards intersubjective values-based indicators. Sustainability, 5(7), 3035-3059. Retrieved May 26, 2020, from https://doi.org/10.14288/1.0378030

Eisner, E. (2002). What the arts teach and how it shows. In Chapter 4, The Arts and the Creation of Mind. New Haven, Connecticut: Yale University Press, pp. 70-92.

Eisner, E. (2005). Opening a shuttered window: An introduction to a special section on the arts and the intellect. Phi Delta Kappan, 87(1), 14-18.

Emas, R. (n.d.) Brief for GSDR 2015. The concept of sustainable development: Definition and defining principles. Retrieved May 26, 2020, from https://sustainabledevelopment.un.org/con tent/documents/5839GSDR\%202015_SD_concept_definiton_rev.pdf

Erzen, J. (2005). An ecological approach to art education: Environmental aesthetics. International Journal of Education through Art, 1(2), 179-186.

Folkerts, H., et al. (2015). Facing forward: Art \& theory from a future perspective. Amsterdam University Press. 
Freedman, K. (2003). Teaching visual culture. Teachers College Press.

Freire, P. (1970). Pedagogy of the oppressed. Herter and Herter.

Global Education Monitoring report. (2016). What is the 'whole school approach' to environmental education? Retrieved June 03, 2020, from https://gemreportunesco.wordpress.com/2016/11/15/ what-is-the-whole-school-approach-to-environmental-education/

Graham, M. A. (2007). Art, ecology and art education: Locating art education in a critical placebased pedagogy. Studies in Art Education, 48(4), 375-391.

Groys, B. (2014a). On the new. Verso.

Groys, B. (2014b). On art activism. Retrieved May 26, 2020, from https://www.e-flux.com/journal/ 56/60343/on-art-activism/

Hawkes, J. (2001). The fourth pillar of sustainability: Culture's essential role in public planning. Melbourne, Vic: Cultural Development Network.

Hickman, R. (2010). Why we make art and why it is taught. Bristol, UK, Chicago, USA: Intellect.

Illeris, H. (2017). Subjectivation, togetherness, environment: Potentials of participatory art for art education for sustainable development (AESD). Nordic Journal of Art and Research, 6(1), 1-16.

IISD. (n.d). Sustainable development. Retrieved May 26, 2020, from https://www.iisd.org/topic/sus tainable-development

Kumar, S. (2010). Art for art's sake. In E. Assadourian, et al. (Eds.), State of the world, 2010: Transforming cultures: From consumerism to sustainability: A Worldwatch Institute report on progress toward a sustainable society. New York, NY: W.W. Norton \& Company.

Lawton, P. H., Walker, M. E., \& Green, M. (2019). Community-based Art Education across the Lifespan: Finding common ground. New York and London: Teachers College Press.

Lindström, L. (2009). Mediated action and aesthetic learning: themes in Swedish studies 1995-2008. In L. Lindström (Ed.), Nordic visual arts education in transition: A research review (pp. 52-79). Stockholm: Swedish Research Council.

Macdonald, A., Ásthildur, J. (2014). Participatory virtues in art education for sustainability. In T. Jokela \& G. Coutts (Eds.), Relate north, engagement, art and representation. Rovaniami: Lapland University Press.

Marshall, J. (2004). Articulate images: Bringing the pictures of science and natural history into the art curriculum. Studies in Art Education, 45(2), 135-152.

Mezirow, J. (1991). Transformative dimensions of adult learning. Jossey-Bass.

Özsoy, V. (2016). Arts and design education for sustainable development. Global Journal on Humanites \& Social Sciences, 03, 487-497. Retrieved May 16, 2020, from http://sproc.org/ojs/index. php/pntsbs

Quinn, T., Ploof, J., \& Hochtritt, L. (Eds.). (2012). Art and social justice education: Culture as commons. Routledge.

Royal Academy of Art. (2020). Competencies in art education. Retrieved May 26, 2020, from https://www.kabk.nl/en/studying-at-kabk/competencies?

Siegesmund, R. (1998). Why do we teach art today? Conceptions of art education and their justification. Studies in Art Education, 39(3), 197-214.

Sobel, D. (1998). Mapmaking with children. Heinemann.

Taylor, E. W. (2008). Transformative learning theory. New Directions for Adult and Continuing Education, 119, 5-15.

Thompson, N. (2012). Living as form: Socially engaged art from 1991-2011. New York: Creative Time Books/Cambridge, Massachusetts, and London, England: The MIT Press.

Tinterow, G., \& Loyrette, H. (1994). Origins of impressionism. The Metropolitan Museum of Art. UCLG. (2010). Culture: Fourth pillar of sustainable development. Retrieved May 26, 2020, from http://www.agenda21 culture.net/sites/default/files/files/documents/en/zz_culture4p illarsd_eng.pdf

UN. (n.d). About the sustainable development goals. Retrieved May 26, 2020, from https://www. un.org/sustainabledevelopment/sustainable-development-goals/

UNECE. (2012). Learning for the future: Competences in education for sustainable development. United Nations Economic Commission for Europe. 
UNESCO. (n.d.-a). UN decade of ESD. Retrieved May 26, 2020, from https://en.unesco.org/the mes/education-sustainable-development/what-is-esd/un-decade-of-esd

UNESCO. (n.d.-b). Global action programme on education for sustainable development (20152019). Retrieved May 26, 2020, from https://en.unesco.org/gap/goals

UNESCO. (n.d.-c). Futures of education: The initiative. Retrieved May 26, 2020, from https://en. unesco.org/futuresofeducation/initiative

UNESCO. (2019). Education for sustainable development (ESD). Retrieved May 14, 2020, from https://en.unesco.org/themes/education-sustainable-development

United Nations. (1993). Report of the United nations conference on environment and development, Vol. 1. New York: United Nations.

United Nations. (2002). Report of the world summit on sustainable development. United Nations.

UN News. (2019, September 23). Greta thunberg tells world leaders 'you are failing us', as nations announce fresh climate action. Retrieved May 26, 2020, from https://news.un.org/en/story/2019/ $09 / 1047052$

Heeswijk, V., \& Rendón, G., et al. (2018). Lesson plan for public faculty no. 11: Imagining a curriculum for sunset park. In G. Sholette (Ed.), Arts as social action: An introduction to the principles and practices of teaching social practice art (pp. 245-249). Allworth Press.

Washington, H. (2018). Education for wonder. Education Sciences 2018, 8(3), 125. Retrieved May 26, 2020, from https://doi.org/10.3390/educsci8030125

Weintraub, L. (2012). To life! eco art in pursuit of a sustainable planet. University of California Press.

Wilson, B. (2003). Of diagrams and rhizomes: Visual culture, contemporary art, and the impossibility of mapping the content of art education. Studies in Art Education, 44(3), 214-229.

Raphael Vella is Associate Professor of Art Education at the University of Malta, where he lectures in art education and socially engaged art. He has published extensively about issues of identity, contemporary art, curatorial practices and education. Books include Artist-Teachers in Context: International Dialogues (Sense, Rotterdam, 2016) and Art-Ethics-Education (co-edited with Carl-Peter Buschkühle and Dennis Atkinson; BrilllSense, Rotterdam, 2020). He has also worked as a freelance curator with international artists and emerging artists in Malta and was co-curator of the Malta Pavilion at the Venice biennale in 2017.

Censu Caruana is currently a full-time lecturer at CEER - Malta's University Centre for Environmental Education and Research. Censu has for the past thiry years been very active in the Social and Development NGO scene, both locally and at a European level. He is an established mentor and trainer of various Civil Society Organisations. Recently he conducted a Mapping Study on Social Enterprises in Malta.

Charmaine Zammit is an Education Officer of Art Education within the Ministry for Education in Malta. She is also a part-time lecturer of Art Education at the University of Malta within the Department of Arts, Open Communities and Adult Education and at the Department for Inclusion and Access to Learning at the Faculty of Education. Her main areas of interest include Art Education, Visual Literacy, Museum Education, Holistic Learning and Community Outreach Projects. 